\title{
Nutrient and Anti-Nutrient Composition of Extruded Cereal Flours Fortified with Grain Amaranth, Baobab and Orange-fleshed Sweet Potato Powder
}

\author{
Sanya Emmaculate ${ }^{1}$, Okoth M. Wandayi ${ }^{1}$, Abong' G. Ooko ${ }^{1} \&$ Mugalavai V. Kadenyeka ${ }^{2}$ \\ ${ }^{1}$ Department of Food Science, Nutrition and Technology, University of Nairobi, P.O. Box 29053-00625, \\ Kangemi, Kenya \\ ${ }^{2}$ Department of Family and Consumer Sciences, University of Eldoret, P.O. Box 1125-30100, Eldoret, Kenya \\ Correspondence: Sanya Emmaculate, Department of Food Science, Nutrition and Technology, University of \\ Nairobi, P.O. Box 29053-00625, Kangemi, Kenya. Tel: 254-700-631-741. E-mail: \\ emmaculatesanya6@gmal.com
}

Received: July 21, $2020 \quad$ Accepted: September 1, $2020 \quad$ Online Published: October 6, 2020

doi:10.5539/jfr.v9n6p21 URL: https://doi.org/10.5539/jfr.v9n6p21

\begin{abstract}
A majority of households in Sub-Saharan Africa utilize cereal-based flours in the preparation of most of their staples. However, the micronutrient contents of these cereal-based flours are low with higher levels of anti-nutrients. Food to food fortification is being used as an alternative to improve the micronutrient content of the cereal-based flours. This study sought to develop an extruded composite flour using sorghum and maize as the cereal base and baobab, grain amaranth and orange-fleshed sweet potatoes as the fortificants. A completely randomized design in factorial arrangement with ingredient ratio and extrusion as factors and seven levels was used to develop different formulations of the composites. Fortification of sorghum-maize cereal flour blends with amaranth, baobab and orange-fleshed sweet potato powder resulted in a significant $(\mathrm{p}<0.05)$ increase in the protein, beta-carotene, iron and zinc contents, on average, $8.99 \pm 1.03 \mathrm{~g} / 100 \mathrm{~g}, 895.90 \pm 346.85 \mathrm{mg} / 100 \mathrm{~g}, 11.81 \pm$ $9.73 \mathrm{mg} / 100 \mathrm{~g}$ and $1.74 \pm 0.18 \mathrm{mg} / 100 \mathrm{~g}$ dry weight basis respectively. High grain amaranth levels in the formulations significantly $(\mathrm{p}<0.05)$ increased the phytate content whereas tannin content was significantly lower in low sorghum formulations. Conversely, extrusion of the composite flours significantly $(\mathrm{p}<0.05)$ reduced protein and beta-carotene contents by $4.7 \%$ and $40.9 \%$ respectively. Extrusion and its interaction with ingredient ratio significantly $(\mathrm{p}<0.05)$ affected the proximate, mineral and anti-nutrient composition of the composite flours. Both the fortificants and extrusion play a role in the reduction of anti-nutrients and therefore future studies should focus on other treatments that can be used together with extrusion to reduce anti-nutrients.
\end{abstract}

Keywords: Anti-nutrients, composite flours, extrusion, fortificant, micronutrient

\section{Introduction}

Food to food fortification is one of the nutrition interventions and strategies employed to alleviate micronutrient deficiencies in resource-poor countries (Chadare et al., 2019; De Groote et al., 2020). Micronutrient deficiency in Sub-Saharan Africa (SSA) is as high as 49\% among households (Fraval et al., 2019). Harika et al., (2017) estimated that children below the age of five years had a 35-63\%, 32-63\% and 15-35\% zinc, iron and vitamin A deficiencies respectively. $24 \%$ of Kenyan children below the age of five are stunted due to poverty and poor nutrition (Ndemwa et al., 2017). Milk, eggs, fish and meat are good sources of protein but their high costs affect their availability in most developing countries households hence the need to improve the nutrient composition of readily available cereals (Manary \& Callaghan-Gillespie, 2020).

Considering that the diets of most of the communities in sub-Saharan Africa (SSA) are cereal-based (Ekpa et al., 2019; Van Ittersum et al., 2016), nutrients such as protein, iron, zinc, beta carotene and folate have been incorporated in them for delivery to the population. Fortification of wheat and maize flour has been necessitated by insufficient levels and limited bioavailability of these micronutrients (Aslam et al., 2018). The ever-evolving nature and diversified processing seeking to address various gaps in the nutritional and physicochemical quality preferences by various populations also necessitates fortification of these cereal flours (Asaam et al., 2018; Mitchell et al., 2019). 
According to Brown et al., ( 2010), the recommended zinc fortification levels for cereal flours across the globe were 1.4-3.3 mg $100 \mathrm{~g}^{-1}$. The blending of flours rather than the use of mineral supplements has been proposed as one of the cost-effective and sustainable techniques of food fortification in SSA. Other than improving micronutrient levels in the flours, blending also induces other nutritional and health benefits such as improved protein and fibre contents. Adeyeye (Adeyeye, 2016) reported that whereas wheat had a fibre content of $1.42 \pm$ $0.05 \%$, sorghum recorded a higher content of $2.32 \pm 0.14 \%$ which makes it a good fortificant of fibre. Since sorghum starch has been shown to have poor digestibility (Kulamarva, Sosle, \& Raghavan, 2009), compositing it with other flours promotes its acceptability and sensory attributes. According to Stefoska-Needham et al., (2015) and Vila-Real et al., (2017), incorporation of other foods into cereal flours is necessary due to the low level of mineral and protein contents.

Foods rich in micronutrients such as orange-fleshed sweet potato (OFSP), baobab pulp and grain amaranth have been composited with cereal flours in efforts to improve the micronutrient contents. The beta-carotene rich property of OFSP has enabled its utilization for mitigation of vitamin A deficiencies (VAD) through its incorporation into other foods (Owade et al., 2018). Although Abong' et al., (2020) indicated that the leaves of OFSP have higher beta carotene content than the roots, the roots are still the most consumed edible part of the OFSP. Incorporation of OFSP flour in maize increased the crude fibre and carotenoids by $2.19-2.69 \%$ and 160.26-205.22 $\mu \mathrm{g} / \mathrm{g}$ respectively (Ukom et al., 2019).

Baobab, a deciduous tree that originated in Africa is mainly found in scrubland and savannah vegetation (Abdulkarim et al., 2014). The baobab fruit is rich in vitamin C, fibre, potassium, calcium, iron and magnesium (Muthai et al., 2017). Studies on flour blends using baobab pulp powder have shown improved rheological and mineral content of cereal flours (Mounjouenpou et al., 2018). According to Tanimola et al., (2016), grain amaranth is rich in micronutrients such as zinc $(6.27 \mathrm{mg} / 100 \mathrm{~g})$, iron $(11.00 \mathrm{mg} / 100 \mathrm{~g})$ and calcium $(33.29 \mathrm{mg} / 100 \mathrm{~g})$, of which their deficiency is of great public health importance. Easy availability of OFSP, baobab and grain amaranth in SSA makes their utilization in composite flour formulation viable. However, evaluation of the three ingredients as possible fortificants of cereal flours has not been extensively done. The current study evaluates a novel product developed through fortification of cereal flours for improved nutritional composition.

\section{Materials and Methods}

\subsection{Raw Material Acquisition}

All the raw materials were purchased from different parts of Kenya. White maize was purchased from Eldoret market. Pale-red sorghum (E71) from Busia was purchased through McKnight Sorghum research team and pale cream grain amaranth was purchased from Bungoma. Baobab powder was purchased from Mombasa and stored at the University of Eldoret Food Processing Centre at $25^{\circ} \mathrm{C}$. Sweet potato puree, was purchased form Organi Ltd in Homabay and stored in a deep freezer at $-20^{\circ} \mathrm{C}$. Each of the raw materials was purchased in packs of 10 $\mathrm{kg}$

\subsection{Sample Preparation}

The grains were washed and dried in a forced draft oven at $60{ }^{\circ} \mathrm{C}$ for $24 \mathrm{~h}$ to a moisture content of $12 \%$. The frozen orange-fleshed sweet potato puree was thawed in warm water before drying it in the oven at $60{ }^{\circ} \mathrm{C}$ for $6 \mathrm{~h}$. They were then milled in a hammer mill fitted with $800 \mu \mathrm{m}$ sieve to obtain whole-milled flours and stored in clean buckets.

\subsection{Formulation of the Composite Flours}

A completely randomized design in factorial arrangement with extrusion and formulation as main factors was used in the production of the flours. The formulations were based on findings of the nutritional profile of each of the ingredients to meet the Recommended Dietary Allowance of children below the age of five as per World Health Organization recommendations. Nutrisurvey linear programming software embedded with WHO RDA for children was used in the formulation of the flours. The formulations targeted $25 \%$ of beta-carotene, iron and zinc contents and $15 \%$ of protein. Seven different formulations with varying ratios of maize, sorghum, grain amaranth, baobab and orange-fleshed potatoes were arrived at using Nutrisurvey as presented in (Table 1). The raw materials were mixed and half of each mixture stored separately for use in comparison to the extruded mixture. The moisture content of the other half was raised to $35 \%$ by adding water and mixing thoroughly and extruded at $160^{\circ} \mathrm{Cin}$ a single screw extruder (TechnoChem, Indiana, USA) with a screw rotation of 800rpm.The extruded products were dried at $50^{\circ} \mathrm{C}$ for $4 \mathrm{~h}$, milled and vacuum-packed. 
Table 1. Composite flour formulations

\begin{tabular}{lcccccl}
\hline \multirow{2}{*}{ Formulation } & \multicolumn{5}{c}{ Ingredient proportion (\%) } & \multirow{2}{*}{ Description } \\
\cline { 2 - 6 } & Maize & Sorghum & Amaranth & OFSP & Baobab & \\
\hline A & 30 & 35 & 20 & 10 & 5 & Varying cereals and fortificants \\
B & 42.5 & 22.5 & 5 & 15 & 15 & $\begin{array}{l}\text { More maize than sorghum } \\
\text { with constant fortificants }\end{array}$ \\
C & 22.5 & 42.5 & 5 & 15 & 15 & $\begin{array}{l}\text { More sorghum than maize } \\
\text { with constant fortificants }\end{array}$ \\
& & & & & & Equal maize and sorghum, \\
D & 32.5 & 32.5 & 5 & 15 & 15 & \\
& & & & & & constant fortificants \\
E & 65 & 0 & 5 & 15 & 15 & Maize plus constant fortificants \\
F & 0 & 65 & 5 & 15 & 15 & Sorghum plus constant fortificants \\
G & 20 & 45 & 5 & 15 & 15 & Variant of formulation C \\
\hline
\end{tabular}

\subsection{Analytical Methods}

\subsubsection{Proximate Composition Determination}

Proximate composition was determined according to AOAC 2012 (AOAC, 2012) methods. Ash content was analyzed as per method number AOAC 942.05:2012, moisture content was according to method number AOAC 976.08:2012, the nitrogen content was done by Kjeldahl method number AOAC 988.05:2012 and converted to protein by multiplying with a factor of 6.25 . The crude fibre was determined by gravimetric method according to method number AOAC 958.06:2012 while fat content was determined by Soxhlet method number AOAC 942.05:2012.

Carbohydrates were determined by the difference:

Carbohydrates $=(100 \%-[\%$ protein $+\%$ fat $+\%$ moisture $+\%$ ash $+\%$ Fiber $])$

Energy content was determined by the WHO/FAO (WHO/FAO, 2003) factor; Energy= $4 \mathrm{kcal} / \mathrm{g}$ (protein) 9 $\mathrm{kcal} / \mathrm{g}$ (fat)+ $4 \mathrm{kcal} / \mathrm{g}$ (carbohydrates).

\subsubsection{Determination of Beta-carotene Content}

Beta-carotene was done according to a method described by Biswas et al (Biswas et al., 2011). A $2 \mathrm{~g}$ sample was extracted using a pestle and motor with small portions of acetone until the residual turned colourless. All the extract was then combined in a $100 \mathrm{~mL}$ volumetric flask. Approximately $25 \mathrm{~mL}$ of the extract was transferred to a $50 \mathrm{~mL}$ round-bottomed flask and evaporated to dryness in a rotary evaporator at $60{ }^{\circ} \mathrm{C}$. Petroleum spirit, approximately $1 \mathrm{~mL}$, was added to dissolve the $\beta$-carotene. The $\beta$-carotene was then eluted through a packed column and the absorbance of the eluent read at $450 \mathrm{~nm}$. The $\beta$-carotene content was then calculated from the $\beta$-carotene standard curve.

\subsubsection{Determination of Iron and Zinc Contents}

Iron and zinc were determined by a modification of the method described by Puwastien et al (Puwastien et al., 2011) using Inductively Coupled Plasma-Optical Emission Spectrometry (ICP-OES). Approximately $0.5 \mathrm{~g}$ of the samples, blanks, positive control and negative controls were weighed into Teflon tubes and $6 \mathrm{~mL}$ of concentrated $\mathrm{HNO}_{3}$ and $3 \mathrm{~mL}$ of $\mathrm{H}_{2} \mathrm{O}_{2}$ added. The vessels were left to vent in a fume hood for $30 \mathrm{~min}$ and then capped. They were then placed on the rotor and inserted into the microwave oven (Anton Paar MULTI WAVE PRO 50 HZ 10HF100) with the microwave power set at a maximum of $1500 \mathrm{~W}$ and digested according to manufacturer's instructions until a clear digest was obtained. They were then transferred to centrifuge tubes and the volume adjusted to $50 \mathrm{~mL}$. The samples and quality control standards were then placed on the autosampler (Agilent Technologies 5110) for analysis and the results read. The $\mathrm{Zn}$ and Fe content of the sample expressed in $\mathrm{mg} / \mathrm{Kg}$ of the product was calculated using the formula:

\section{$\mathrm{Zn} / \mathrm{Fe}$ content $=(\boldsymbol{c i}-\boldsymbol{c b}) * \boldsymbol{v} * d . f / w$}

Where;

$\mathrm{ci}=\mathrm{Zn}$ or Fe content of test solution expressed in $\mathrm{mg} / \mathrm{l}$ read from the calibration curve.

$\mathrm{cb}=$ Content of blank solution in $\mathrm{mg} / \mathrm{l} \mathrm{read}$ from calibration curve 
d. $\mathrm{f}=$ Dilution factor

$\mathrm{w}=$ Sample weight

\subsubsection{Determination of Phytate Content}

Phytic acid content was determined using the method by Latta et al (Latta \& Eskin, 1980) Approximately $1 \mathrm{~g}$ of the sample was defatted by addition of $10 \mathrm{~mL}$ of petroleum ether and left to stand for two hours. The supernatant was discarded and the samples allowed to dry; $10 \mathrm{~mL}$ of $10 \%$ hydrochloric acid was added and the suspension centrifuged (Dr Ngerber, K. Schneider \& Co, Zurich) at $482.97 \mathrm{~g}$ for $10 \mathrm{~min}$ and the supernatant transferred into $100 \mathrm{~mL}$ volumetric flask. This was repeated 4 times. Approximately $2 \mathrm{~mL}$ of the sample was transferred to a 50 $\mathrm{mL}$ volumetric flask and $2 \mathrm{~mL}$ of Wade reagent $(0.03 \%$ iron chloride+ $0.3 \%$ Sulfosalicylic acid) added and topped up to $10 \mathrm{~mL}$ with water. Absorbance was read using a single-beam spectrophotometer (Spectronic 1001, Milton Roy Company, USA) at $500 \mathrm{~nm}$ wavelength. The phytate content was calculated using the phytic acid standard curve and the results expressed in $\mathrm{g} / 100 \mathrm{~g}$ dry weight.

\subsubsection{Determination of Tannin Content}

Tannin content was analyzed according to AOAC (2012) method number 952.0:2012. Briefly,0.5g of the sample was weighed and $50 \mathrm{~mL}$ of water added and vortexed for $5 \mathrm{~min}$ and allowed to settle. The supernatant was then decanted into a clean conical flask. Approximately $2 \mathrm{~mL}$ of Folin Denis reagent, prepared according to Ferreira et al., (2004) was added to $75 \mathrm{~mL}$ of distilled water followed by the addition of $2 \mathrm{~mL}$ of the sample and $5 \mathrm{~mL}$ of concentrated sodium carbonate. The volume was then adjusted to $100 \mathrm{~mL}$ by addition of distilled water and allowed to stand for $40 \mathrm{~min}$. Absorbance was then read at $725 \mathrm{~nm}$ using a single beam spectrophotometer (Spectronic 1001, Milton Roy Company, USA) at $500 \mathrm{~nm}$ wavelength and the results expressed in $\mathrm{g} / 100 \mathrm{~g}$ dry weight.

\subsection{Statistical Analysis}

Statistical analysis of the data was done in the $R$ Project for Statistical Computing, R-3.6.3 (R Core Team, 2019). The nutrient and anti-nutrient contents were converted to dry weight basis (dwb) and descriptive statistics including the mean and the standard deviation obtained. Normality of the data was tested using the Wilk's Shapiro test. Exploratory analysis of the data was done using the Pearson correlation. Inferential statistics were done by ANOVA, whereby means that were statistically different were separated using the Tukey's HSD test. Significant differences were tested at $\mathrm{p}<0.05$.

\section{Results}

\subsection{Proximate Composition of the Raw Materials}

Proximate composition of the raw materials was statistically $(\mathrm{p}<0.05)$ different as shown in Table 2. Grain amaranth had a fat, protein and fibre content of $9.03 \pm 0.23,15.26 \pm 0.34$ and $9.28 \pm 0.44 \mathrm{~g} / 100 \mathrm{~g} \mathrm{dwb}$, respectively, which was significantly $(\mathrm{p}<0.05)$ higher than the combination of these nutrients reported in other raw flour samples whereas the baobab powder had the highest ash content $(9.25 \pm 0.09 \mathrm{~g} / 100 \mathrm{~g} \mathrm{dwb})$.

The micronutrient content of the raw flour significantly $(\mathrm{p}<0.05)$ differed from each other (Table 3$)$. Iron, zinc and beta-carotene contents were the micronutrients of interest in this study and they were highest in sorghum, grain amaranth and orange-fleshed sweet potatoes respectively.

\subsection{Anti-nutrient Content of Raw Flours}

Tannins were highest in sorghum flour $(335.08 \pm 16.53 \mathrm{mg} / 100 \mathrm{~g})$ whereas the phytates were highest in baobab powder $(191.95 \pm 0.41 \mathrm{mg} / 100 \mathrm{~g}), \mathrm{p}<0.05$ (Figure 1).

Table 2. Proximate composition of raw flours used in formulating composite flours (per $100 \mathrm{~g} \mathrm{dwb}$ )

\begin{tabular}{llllllll}
\hline $\begin{array}{l}\text { Raw } \\
\text { flour }\end{array}$ & $\begin{array}{l}\text { Moisture } \\
(\mathbf{g})\end{array}$ & $\begin{array}{l}\text { Protein } \\
(\mathrm{g})\end{array}$ & Fat $(\mathrm{g})$ & $\begin{array}{l}\text { Fibre* } \\
(\mathbf{g})\end{array}$ & $\begin{array}{l}\text { Ash* } \\
(\mathrm{g})\end{array}$ & $\begin{array}{l}\text { Carbohydrates* } \\
(\mathbf{g})\end{array}$ & $\begin{array}{l}\text { Energy } \\
\text { value }(\text { Kcal})\end{array}$ \\
\hline Maize & $13.76 \pm 0.60^{\mathrm{b}}$ & $4.89 \pm 0.07^{\mathrm{c}}$ & $4.56 \pm 0.12^{\mathrm{c}}$ & $2.33 \pm 0.03^{\mathrm{b}}$ & $1.35 \pm 0.02^{\mathrm{e}}$ & $86.87 \pm 0.00^{\mathrm{a}}$ & $408.06 \pm 0.78^{\mathrm{b}}$ \\
Sorghum & $11.06 \pm 0.15^{\mathrm{c}}$ & $7.19 \pm 0.05^{\mathrm{b}}$ & $6.32 \pm 0.91^{\mathrm{b}}$ & $3.03 \pm 0.07^{\mathrm{b}}$ & $1.68 \pm 0.00^{\mathrm{d}}$ & $81.79 \pm 0.92^{\mathrm{b}}$ & $412.77 \pm 4.30^{\mathrm{a}}$ \\
Amaranth & $12.30 \pm 0.69^{\mathrm{bc}}$ & $15.26 \pm 0.34^{\mathrm{a}}$ & $9.03 \pm 0.23^{\mathrm{a}}$ & $9.28 \pm 0.44^{\mathrm{a}}$ & $2.95 \pm 0.05^{\mathrm{c}}$ & $63.48 \pm 0.17^{\mathrm{d}}$ & $396.25 \pm 2.74^{\mathrm{c}}$ \\
Baobab & $17.42 \pm 0.62^{\mathrm{a}}$ & $0.42 \pm 0.01^{\mathrm{d}}$ & $0.70 \pm 0.06^{\mathrm{d}}$ & $10.48 \pm 0.41^{\mathrm{a}}$ & $9.25 \pm 0.09^{\mathrm{a}}$ & $79.15 \pm 0.43^{\mathrm{c}}$ & $324.58 \pm 2.31^{\mathrm{e}}$ \\
OFSP & $14.06 \pm 0.02^{\mathrm{b}}$ & $6.09 \pm 0.02^{\mathrm{c}}$ & $0.54 \pm 0.03^{\mathrm{d}}$ & $2.89 \pm 0.03^{\mathrm{b}}$ & $5.03 \pm 0.01^{\mathrm{b}}$ & $85.46 \pm 0.09^{\mathrm{a}}$ & $371.00 \pm 0.01^{\mathrm{d}}$ \\
$\%$ CV & 16.7 & 75.7 & 82.6 & 65.0 & 72.7 & 11.1 & 11.2 \\
p-value & $<0.001$ & $<0.001$ & $<0.001$ & $<0.001$ & $<0.001$ & $<0.001$ & $<0.001$ \\
\hline
\end{tabular}


The values are mean of duplicate samples \pm SD. Values with different letters in the superscript along a column are statistically different at $\mathrm{p}<0.001$. Moisture values are in $\mathrm{g} / 100 \mathrm{~g}$ wet weight basis (wwb).

Table 3. Micronutrient composition of raw flours used in formulating blended flours (per 100g dwb)

\begin{tabular}{llll}
\hline Raw flour & Iron $(\mathbf{m g})$ & Zinc $(\mathbf{m g})$ & Beta-carotene $(\mathbf{m g})$ \\
\hline Maize & $2.09 \pm 0.02^{\mathrm{e}}$ & $0.20 \pm 0.02^{\mathrm{b}}$ & $\mathrm{Nd}$ \\
Sorghum & $18.57 \pm 0.03^{\mathrm{a}}$ & $0.14 \pm 0.00^{\mathrm{c}}$ & $\mathrm{Nd}$ \\
Amaranth & $12.30 \pm 0.14^{\mathrm{c}}$ & $0.62 \pm 0.01^{\mathrm{a}}$ & $\mathrm{Nd}$ \\
Baobab & $16.07 \pm 0.27^{\mathrm{b}}$ & $0.12 \pm 0.00^{\mathrm{c}}$ & $\mathrm{Nd}$ \\
OFSP & $6.50 \pm 0.02^{\mathrm{d}}$ & $0.16 \pm 0.00^{\mathrm{c}}$ & $3268.45 \pm 6.64$ \\
$\% \mathrm{CV}$ & 58.1 & 81.8 & N/A \\
p-value & $<0.001$ & $<0.001$ & \\
\hline
\end{tabular}

The values are mean of duplicate samples \pm SD. Values with different letters in the superscript are statistically different at $\mathrm{p}<0.05$. Nd- not detected.

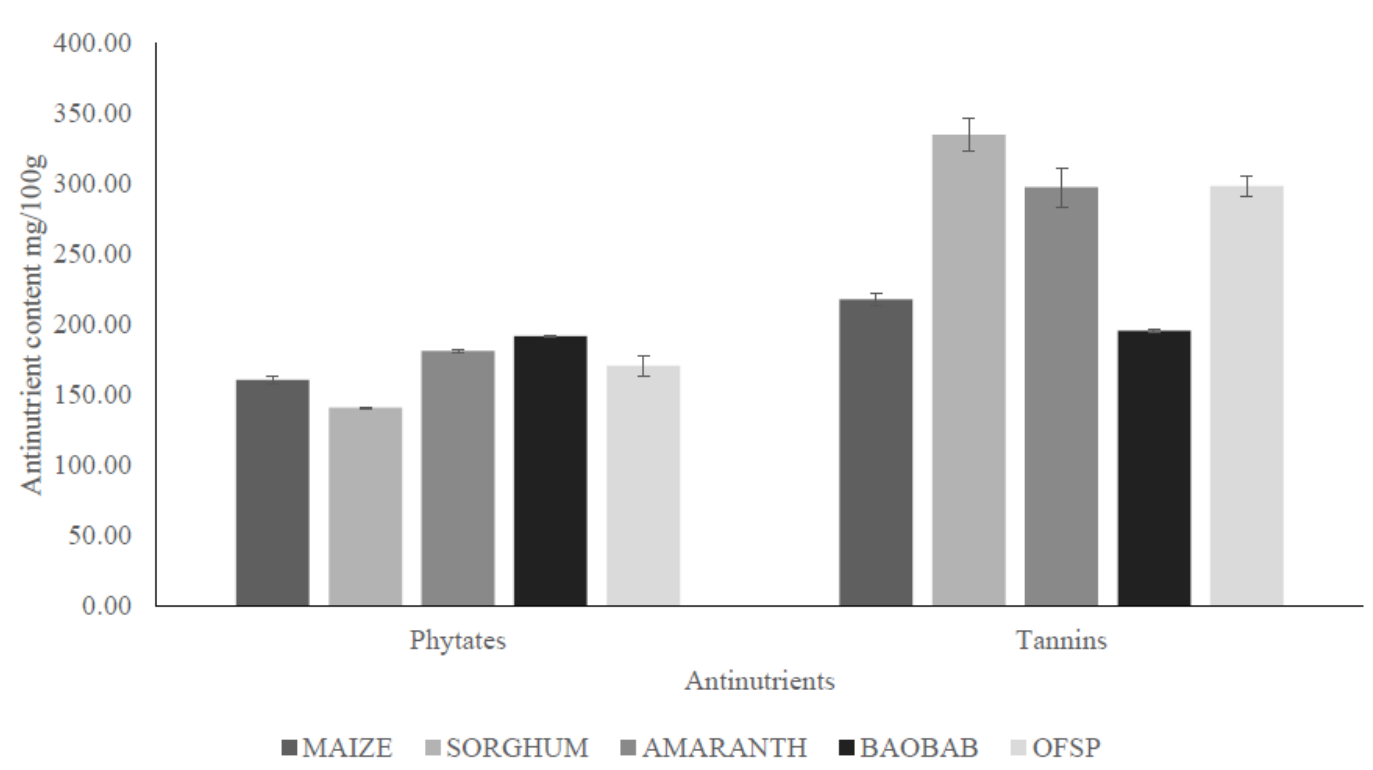

Figure 1. Antinutrient content ( $\mathrm{mg} / 100 \mathrm{~g}$ dry weight) of raw flours used in formulating blended flours

\subsection{Proximate Composition of Composite Flours}

Proximate composition of flours was significantly affected by the ratio of the ingredients, extrusion and the interaction of the two factors. Addition of the fortificants significantly $(\mathrm{p}<0.05)$ affected the protein, ash and carbohydrate contents (Table 4). Sample A in which the highest content of amaranth grain (20\%) was added had significantly $(\mathrm{p}<0.001)$ high contents of protein and ash. Increasing maize levels resulted in significantly $(\mathrm{p}<0.05)$ higher carbohydrate contents compared to sorghum.

Extrusion of the composite flours significantly improved the fat and fibre contents and the energy values while reducing the ash, moisture, protein, fibre and carbohydrate contents as shown in Figure 2. 
Table 4. Effect of fortification of cereal flours with baobab, orange-fleshed sweet potato and amaranth grain powders on their proximate composition (per $100 \mathrm{~g} \mathrm{dwb}$ )

\begin{tabular}{llllllll}
\hline $\begin{array}{l}\text { Blended } \\
\text { flours }\end{array}$ & $\begin{array}{l}\text { Moisture } \\
(\mathrm{g})\end{array}$ & $\begin{array}{l}\text { Protein } \\
(\mathrm{g})\end{array}$ & $\begin{array}{l}\text { Fat } \\
(\mathrm{g})\end{array}$ & $\begin{array}{l}\text { Fibre } \\
(\mathrm{g})\end{array}$ & $\begin{array}{l}\text { Ash } \\
(\mathrm{g})\end{array}$ & $\begin{array}{l}\text { Carbohydrates } \\
(\mathrm{g})\end{array}$ & $\begin{array}{l}\text { Energy } \\
\text { values }(\text { Kcal})\end{array}$ \\
\hline $\mathrm{A}$ & $10.59 \pm 3.39^{\mathrm{a}}$ & $10.36 \pm 0.89^{\mathrm{a}}$ & $4.33 \pm 0.99^{\mathrm{a}}$ & $0.87 \pm 0.04^{\mathrm{a}}$ & $0.72 \pm 0.02^{\mathrm{a}}$ & $84.08 \pm 0.30^{\mathrm{ab}}$ & $416.70 \pm 5.13^{\mathrm{a}}$ \\
B & $8.82 \pm 4.96^{\mathrm{a}}$ & $8.85 \pm 0.33^{\mathrm{b}}$ & $4.16 \pm 1.56^{\mathrm{a}}$ & $0.98 \pm 0.16^{\mathrm{a}}$ & $0.61 \pm 0.05^{\mathrm{b}}$ & $85.41 \pm 1.77^{\mathrm{ab}}$ & $414.42 \pm 8.29^{\mathrm{a}}$ \\
C & $9.23 \pm 4.38^{\mathrm{a}}$ & $9.24 \pm 0.04^{\mathrm{ab}}$ & $3.87 \pm 1.24^{\mathrm{a}}$ & $0.95 \pm 0.08^{\mathrm{a}}$ & $0.63 \pm 0.04^{\mathrm{b}}$ & $85.32 \pm 1.14^{\mathrm{ab}}$ & $413.04 \pm 6.63^{\mathrm{a}}$ \\
D & $11.68 \pm 1.85^{\mathrm{a}}$ & $8.35 \pm 0.78^{\mathrm{b}}$ & $3.91 \pm 1.29^{\mathrm{a}}$ & $0.91 \pm 0.19^{\mathrm{a}}$ & $0.63 \pm 0.03^{\mathrm{b}}$ & $86.36 \pm 0.24^{\mathrm{ab}}$ & $414.05 \pm 8.02^{\mathrm{a}}$ \\
E & $11.22 \pm 3.11^{\mathrm{a}}$ & $7.24 \pm 0.33^{\mathrm{c}}$ & $3.74 \pm 1.15^{\mathrm{a}}$ & $0.97 \pm 0.24^{\mathrm{a}}$ & $0.56 \pm 0.01^{\mathrm{c}}$ & $87.62 \pm 0.52^{\mathrm{a}}$ & $413.10 \pm 7.36^{\mathrm{a}}$ \\
F & $10.55 \pm 2.34^{\mathrm{a}}$ & $9.41 \pm 0.41^{\mathrm{ab}}$ & $3.77 \pm 1.45^{\mathrm{a}}$ & $0.91 \pm 0.10^{\mathrm{a}}$ & $0.62 \pm 0.02^{\mathrm{b}}$ & $85.29 \pm 0.96^{\mathrm{ab}}$ & $412.71 \pm 7.58^{\mathrm{a}}$ \\
G & $7.84 \pm 5.57^{\mathrm{a}}$ & $9.45 \pm 0.27^{\mathrm{ab}}$ & $3.88 \pm 1.69^{\mathrm{a}}$ & $1.07 \pm 0.01^{\mathrm{a}}$ & $0.54 \pm 0.01^{\mathrm{c}}$ & $85.05 \pm 1.95^{\mathrm{ab}}$ & $412.95 \pm 8.49^{\mathrm{a}}$ \\
$\%$ CV & 36.6 & 11.5 & 30.7 & 14.4 & 9.6 & 1.7 & 1.7 \\
p-value & 0.790 & $<0.001$ & 0.996 & 0.576 & $<0.001$ & 0.012 & 0.989 \\
\hline
\end{tabular}

Values are means of triplicates for a sample. All values are in $\mathrm{g}$ per 100g whereas those of carbohydrates and energy values are to be multiplied with a factor of 10 and 100, respectively. All the values are in dry weight basis (dwb) except for moisture (wwb). The error bars represent the standard deviation.

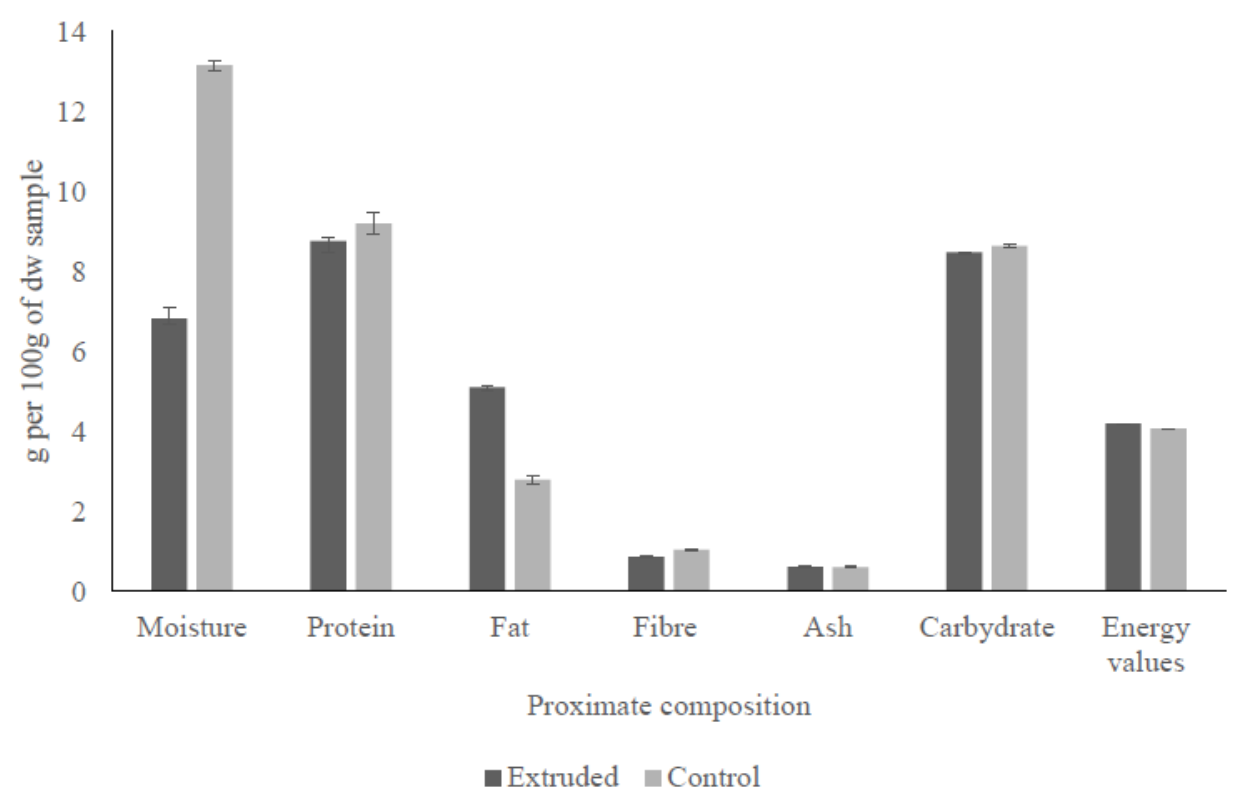

Figure 2. Effect of extrusion on the proximate composition of fortified cereal flours

All values are in g per $100 \mathrm{~g}$ except and moisture which is on a wwb. Carbohydrate and energy values are to be multiplied by a factor of 10 and 100, respectively. The error bars represent the standard deviations.

Extrusion and ingredient ratio interaction significantly $(\mathrm{p}<0.05)$ affected the proximate composition of the composite flours as shown in Table 5. Extrusion significantly $(\mathrm{p}<0.001)$ increased the energy contents of high sorghum formulations. Increasing grain amaranth in the formulations resulted in significantly $(p<0.001)$ higher protein and ash contents in both the extruded and non-extruded treatments. Extrusion induced higher fat contents while decreasing the moisture contents in all the formulations as compared to the non-extruded samples $(\mathrm{p}<0.001)$. The formulations that underwent extrusion all had significantly $(\mathrm{p}<0.05)$ higher carbohydrate contents notwithstanding the ratio of ingredients incorporated. An increasing proportion of maize in the formulation resulted in higher levels of fibre both in the extruded and non-extruded formulations $(\mathrm{p}<0.05)$. 
Table 5. Effect of interaction between formulation and extrusion on the proximate composition of the composite flours (per 100g)

\begin{tabular}{|c|c|c|c|c|c|c|c|c|}
\hline \multicolumn{2}{|c|}{ Formulation } & \multirow{2}{*}{$\begin{array}{l}\begin{array}{l}\text { Moisture } \\
\text { content }(g)\end{array} \\
7.65 \pm 0.01^{\mathrm{d}}\end{array}$} & \multirow{2}{*}{$\begin{array}{l}\text { Protein } \\
\text { (g) }\end{array}$} & \multirow{2}{*}{$\begin{array}{l}\text { Fat }(\mathbf{g}) \\
5.18 \pm 0.02^{\mathrm{e}}\end{array}$} & \multirow{2}{*}{$\begin{array}{l}\text { Fibre }(\mathbf{g}) \\
0.90 \pm 0.03^{\mathrm{d}}\end{array}$} & \multirow{2}{*}{$\begin{array}{l}\operatorname{Ash}(\mathbf{g}) \\
0.70 \pm 0.02^{\mathrm{fg}}\end{array}$} & \multirow{2}{*}{$\begin{array}{l}\text { Carbohydrate } \\
\text { (g) }\end{array}$} & \multirow{2}{*}{$\begin{array}{l}\begin{array}{l}\text { Energy values } \\
\text { (Kcal) }\end{array} \\
420.90 \pm 1.90^{\mathrm{d}}\end{array}$} \\
\hline A & Extruded & & & & & & & \\
\hline & Control & $13.53 \pm 0.01^{1}$ & $11.09 \pm 0.51^{\mathrm{f}}$ & $3.47 \pm 0.00^{\mathrm{c}}$ & $0.84 \pm 0.02^{\mathrm{bc}}$ & $0.73 \pm 0.02^{\mathrm{g}}$ & $84.22 \pm 0.04^{\mathrm{c}}$ & $412.50 \pm 1.09^{\mathrm{b}}$ \\
\hline \multirow[t]{2}{*}{ B } & Extruded & $4.53 \pm 0.03^{\mathrm{b}}$ & $9.12 \pm 0.11^{\mathrm{d}}$ & $5.51 \pm 0.03^{\mathrm{f}}$ & $0.84 \pm 0.00^{\mathrm{bc}}$ & $0.65 \pm 0.03^{\mathrm{e}}$ & $83.88 \pm 0.11^{\mathrm{b}}$ & $421.60 \pm 0.30^{\mathrm{d}}$ \\
\hline & Control & $13.12 \pm 0.04^{\mathrm{j}}$ & $8.57 \pm 0.06^{\mathrm{c}}$ & $2.80 \pm 0.01^{\mathrm{b}}$ & $1.12 \pm 0.01^{\mathrm{f}}$ & $0.57 \pm 0.01^{\mathrm{abc}}$ & $86.94 \pm 0.09^{\mathrm{g}}$ & $407.20 \pm 0.00^{\mathrm{a}}$ \\
\hline \multirow[t]{2}{*}{$\mathrm{C}$} & Extruded & $5.44 \pm 0.03^{\mathrm{c}}$ & $9.24 \pm 0.07^{\mathrm{d}}$ & $4.94 \pm 0.01^{\mathrm{d}}$ & $0.89 \pm 0.07^{\mathrm{c}}$ & $0.59 \pm 0.01^{\mathrm{bcd}}$ & $84.33 \pm 0.12^{\text {cd }}$ & $418.80 \pm 0.20^{\mathrm{c}}$ \\
\hline & Control & $13.03 \pm 0.02^{\mathrm{i}}$ & $9.24 \pm 0.01^{\mathrm{d}}$ & $2.79 \pm 0.03^{\mathrm{b}}$ & $1.01 \pm 0.01^{\mathrm{e}}$ & $0.66 \pm 0.01^{\mathrm{ef}}$ & $86.30 \pm 0.06^{\mathrm{ef}}$ & $407.30 \pm 0.10^{\mathrm{a}}$ \\
\hline \multirow[t]{2}{*}{ D } & Extruded & $10.08 \pm 0.01^{\mathrm{g}}$ & $7.68 \pm 0.13^{\mathrm{b}}$ & $5.02 \pm 0.20^{\mathrm{d}}$ & $0.75 \pm 0.05^{\mathrm{a}}$ & $0.63 \pm 0.02^{\mathrm{de}}$ & & $420.90 \pm 2.60^{c}$ \\
\hline & Control & $13.28 \pm 0.03^{\mathrm{k}}$ & $9.03 \pm 0.04^{\mathrm{d}}$ & $2.80 \pm 0.00^{\mathrm{b}}$ & $1.08 \pm 0.01^{\mathrm{f}}$ & $0.62 \pm 0.04^{\mathrm{d}}$ & $86.47 \pm 0.09^{\mathrm{f}}$ & $407.20 \pm 0.20^{\mathrm{a}}$ \\
\hline \multirow[t]{2}{*}{$\mathrm{E}$} & Extruded & $8.52 \pm 0.03^{\mathrm{e}}$ & $6.96 \pm 0.06^{\mathrm{a}}$ & $4.73 \pm 0.02^{\mathrm{c}}$ & $0.77 \pm 0.01^{\mathrm{a}}$ & $0.57 \pm 0.02^{\mathrm{abc}}$ & $87.25 \pm 0.49^{\mathrm{h}}$ & $419.40 \pm 1.60^{\mathrm{c}}$ \\
\hline & Control & $13.91 \pm 0.01^{\mathrm{m}}$ & $7.53 \pm 0.00^{\mathrm{b}}$ & $2.74 \pm 0.02^{\mathrm{b}}$ & $1.18 \pm 0.01^{\mathrm{g}}$ & $0.55 \pm 0.01^{\mathrm{ab}}$ & $88.00 \pm 0.03^{\mathrm{h}}$ & $406.80 \pm 0.00^{\mathrm{a}}$ \\
\hline \multirow[t]{2}{*}{$\mathrm{F}$} & Extruded & $8.53 \pm 0.00^{\mathrm{e}}$ & $9.06 \pm 0.10^{\mathrm{d}}$ & $5.02 \pm 0.01^{\mathrm{d}}$ & $0.83 \pm 0.01^{\mathrm{b}}$ & $0.63 \pm 0.00^{\mathrm{de}}$ & $84.46 \pm 0.12^{\mathrm{d}}$ & $419.30 \pm 0.00^{\mathrm{cd}}$ \\
\hline & Control & $12.58 \pm 0.01^{\mathrm{g}}$ & $9.76 \pm 0.01^{\mathrm{e}}$ & $2.51 \pm 0.01^{\mathrm{a}}$ & $1.00 \pm 0.02^{\mathrm{e}}$ & $0.60 \pm 0.01^{\mathrm{cd}}$ & $86.13 \pm 0.05^{\mathrm{e}}$ & $406.1 \pm 0.10^{\mathrm{a}}$ \\
\hline \multirow[t]{2}{*}{ G } & Extruded & $3.02 \pm 0.03^{\mathrm{a}}$ & $9.68 \pm 0.02^{\mathrm{e}}$ & $5.35 \pm 0.01^{\mathrm{f}}$ & $1.07 \pm 0.00^{\mathrm{f}}$ & $0.54 \pm 0.00^{\mathrm{ab}}$ & $83.36 \pm 0.03^{\mathrm{a}}$ & $420.30 \pm 0.00^{\mathrm{d}}$ \\
\hline & Control & $12.67 \pm 0.02^{\mathrm{h}}$ & $9.22 \pm 0.00^{\mathrm{d}}$ & $2.42 \pm 0.02^{\mathrm{a}}$ & $1.06 \pm 0.01^{\mathrm{ef}}$ & $0.54 \pm 0.01^{\mathrm{a}}$ & $86.75 \pm 0.05^{\mathrm{g}}$ & $405.60 \pm 0.10^{\mathrm{a}}$ \\
\hline
\end{tabular}

Values are means of triplicates for a sample. Values with different letters in the superscript along a column are statistically different at $p<0.05$. All the values are in dry weight basis $(d w b)$ except moisture which is on wwb. Formulation A had varying fortificants, formulation B had more maize and equal fortificants, formulation $\mathrm{C}$ had more sorghum and equal fortificants, formulation $\mathrm{D}$ had equal maize and sorghum with constant fortificants, formulation $\mathrm{E}$ had maize and fortificants, formulation $\mathrm{F}$ had sorghum and the fortificants and formulation $\mathrm{G}$ was a variant of formulation $\mathrm{C}$

\subsection{Micronutrient and Antinutrient Content of Blended Flours}

Beta carotene, phytates and tannin contents in the formulations were significantly $(\mathrm{p}<0.01)$ affected by the ratio of the ingredients, extrusion and the interaction of the two factors. However, the zinc content of the flours was only significantly $(\mathrm{p}<0.001)$ affected by the ratio of the ingredients and the interaction between the ratio of the ingredients and extrusion. Neither the incorporation of the fortificants nor the process of extrusion significantly ( $p>0.05$ ) affected the iron content of the formulations.

The beta-carotene content of the fortified cereal flours was significantly predicted by the moisture content at $p<0.05$ with a variance of $53.1 \%$. The regression equation of the predictor model was as shown in equation 1 .

\section{Equation 1}

$$
y=3+0.01 x
$$

Whereby $\mathrm{y}$ is the beta carotene content and $x$ is the moisture content. $\mathrm{R}^{2}=0.53$

Whereas extrusion significantly $(\mathrm{p}<0.001)$ reduced the beta-carotene content of the cereal flours, it had no significant $(\mathrm{p}>0.05)$ effect on the iron and zinc contents. Treatment with the highest proportion of amaranth (20\%) had the highest level $(1.97 \pm 0.12 \mathrm{mg} / 100 \mathrm{~g} \mathrm{dwb})$ of zinc content at $\mathrm{p}<0.001$. The trends did not change with the inclusion of the second factor (extrusion) as the incorporation of the amaranth grain significantly increased the zinc content $(1.88-2.06 \mathrm{mg} / 100 \mathrm{~g} \mathrm{dwb})$. Incorporating OFSP and amaranth grain powder significantly increased the beta carotene content of the cereal flour (Table 6). Extrusion resulted in higher degradation of beta-carotene in cereal flour with OFSP as compared to that with amaranth grain, $\mathrm{p}<0.05$.

There was significantly $(\mathrm{p}<0.001)$ higher phytate and tannin contents in non-extruded cereal flours than the extruded (Table 7). A higher proportion of sorghum significantly $(\mathrm{p}<0.05)$ increased the tannin and phytate contents with the samples with $65 \%$ sorghum having the phytate and tannin contents of $11.47 \pm 2.17$ and 1329.9 $\pm 265.2 \mathrm{mg} / 100 \mathrm{~g} \mathrm{dwb}$, respectively. The interaction of extrusion and formulation significantly $(\mathrm{p}<0.05)$ affected the phytate and tannin contents of the blended flours (Figures 3 and 4). The phytate contents of cereal flour with the higher proportions of sorghum than maize was found to reduce whereas those with more maize than sorghum recorded lower tannin contents on extrusion at $\mathrm{p}<0.001$. In all the formulations, the tannin content reduced when extrusion was done. Zinc was positively correlated with the phytate content in the cereal flours $(\mathrm{p}<0.05)$ as 
shown in Table 8.

Table 6. Effect of extrusion and formulation of cereal flours with baobab, orange-fleshed sweet potato and grain amaranth powder on their micronutrient content $(\mathrm{mg} / 100 \mathrm{~g} \mathrm{dwb})$

\begin{tabular}{lllll}
\hline \multirow{2}{*}{ Formulation } & \multicolumn{3}{l}{ Micronutrient content (mg/100g) } \\
\cline { 3 - 5 } & & Beta carotene content & Iron content & Zinc content \\
\hline A & Extruded & $1074.4 \pm 1.0^{\mathrm{Ah}}$ & $7.35 \pm 0.10^{\mathrm{Da}}$ & $1.88 \pm 0.12^{\mathrm{Ge}}$ \\
& Control & $1301.5 \pm 13.6^{\mathrm{Ahi}}$ & $5.26 \pm 0.01^{\mathrm{Da}}$ & $2.06 \pm 0.00^{\mathrm{Gi}}$ \\
$\mathrm{B}$ & Extruded & $385.8 \pm 12.0^{\mathrm{Ab}}$ & $14.40 \pm 0.09^{\mathrm{Da}}$ & $1.46 \pm 0.09^{\mathrm{Ga}}$ \\
& Control & $1277.8 \pm 20.8^{\mathrm{Ah}}$ & $4.25 \pm 0.10^{\mathrm{Da}}$ & $1.68 \pm 0.16^{\mathrm{Gbcd}}$ \\
$\mathrm{C}$ & Extruded & $280.3 \pm 1.3^{\mathrm{Aa}}$ & $14.35 \pm 0.02^{\mathrm{Da}}$ & $1.89 \pm 0.05^{\mathrm{Ge}}$ \\
& Control & $1324.7 \pm 20.5^{\mathrm{Ai}}$ & $5.15 \pm 0.13^{\mathrm{Da}}$ & $1.62 \pm 0.07^{\mathrm{Gbcd}}$ \\
$\mathrm{D}$ & Extruded & $693.1 \pm 1.2^{\mathrm{Ad}}$ & $22.12 \pm 0.07^{\mathrm{Da}}$ & $1.59 \pm 0.03^{\mathrm{Gabc}}$ \\
& Control & $1320.8 \pm 13.1^{\mathrm{Ai}}$ & $6.70 \pm 0.02^{\mathrm{Da}}$ & $1.68 \pm 0.04^{\mathrm{Gbcd}}$ \\
$\mathrm{E}$ & Extruded & $1043.9 \pm 12.5^{\mathrm{Ag}}$ & $15.64 \pm 0.07^{\mathrm{Da}}$ & $1.68 \pm 0.03^{\mathrm{Gcd}}$ \\
& Control & $772.3 \pm 1.4^{\mathrm{Ae}}$ & $4.29 \pm 0.02^{\mathrm{Da}}$ & $1.86 \pm 0.08^{\mathrm{Ge}}$ \\
$\mathrm{F}$ & Extruded & $601.9 \pm 19.2^{\mathrm{Ac}}$ & $19.88 \pm 0.09^{\mathrm{Da}}$ & $1.76 \pm 0.02^{\mathrm{Gde}}$ \\
& Control & $885.0 \pm 0.7^{\mathrm{Af}}$ & $6.35 \pm 0.06^{\mathrm{Da}}$ & $1.89 \pm 0.05^{\mathrm{Ge}}$ \\
$\mathrm{G}$ & Extruded & $577.9 \pm 1.3^{\mathrm{Ac}}$ & $11.49 \pm 0.02^{\mathrm{Da}}$ & $1.88 \pm 0.04^{\mathrm{Ge}}$ \\
& Control & $1003.1 \pm 7.0^{\mathrm{Af}}$ & $28.19 \pm 2.67^{\mathrm{Da}}$ & $1.49 \pm 0.02^{\mathrm{Gab}}$ \\
& & $38.7 \%$ & 82.3 & 10.2 \\
$\mathrm{p}$ p-value & & $<0.001$ & 0.219 & $<0.001$ \\
\hline
\end{tabular}

Values with a similar uppercase letter followed by different lowercase letters in the superscript are statistically different at $\mathrm{p}<0.05$ whereas values with a similar uppercase letter followed by similar lowercase letters are statistically similar at $p<0.05$. Values are means of triplicates for a sample.

Table 7. Main effect of extrusion and formulation on tannins and phytate contents of composite flour

\begin{tabular}{lll}
\hline Formulation & Phytates mg/100g & Tannin $\mathbf{~ m g / 1 0 0 g}$ \\
\hline $\mathrm{A}$ & $12.85 \pm 1.70^{\mathrm{Aab}}$ & $757.7 \pm 149.4^{\mathrm{Aa}}$ \\
$\mathrm{B}$ & $6.25 \pm 2.26^{\mathrm{Aabc}}$ & $873.3 \pm 385.6^{\mathrm{Aa}}$ \\
$\mathrm{C}$ & $8.61 \pm 1.04^{\mathrm{Abcd}}$ & $1109.0 \pm 381.7^{\mathrm{Abc}}$ \\
$\mathrm{D}$ & $10.07 \pm 1.61^{\mathrm{Abcd}}$ & $1078.8 \pm 213.5^{\mathrm{Ac}}$ \\
$\mathrm{E}$ & $7.57 \pm 1.91^{\mathrm{Aa}}$ & $570.7 \pm 63.0^{\mathrm{Aab}}$ \\
$\mathrm{F}$ & $11.47 \pm 2.17^{\mathrm{Ad}}$ & $1329.9 \pm 265.2^{\mathrm{Ad}}$ \\
$\mathrm{G}$ & $8.01 \pm 1.08^{\mathrm{Acd}}$ & $1163.0 \pm 225.0^{\mathrm{Ab}}$ \\
$\% \mathrm{CV}$ & 18.8 & 26.8 \\
LSD & 2.56 & 387.9 \\
Extrusion & & \\
Extruded & $8.74 \pm 3.21^{\mathrm{Ba}}$ & $775.0 \pm 215.3^{\mathrm{Ba}}$ \\
Control & $9.78 \pm 1.98^{\mathrm{Bb}}$ & $1191.5 \pm 314.6^{\mathrm{Bb}}$ \\
$\% \mathrm{CV}$ & 28.8 & 27.4 \\
\hline
\end{tabular}

Values with a similar uppercase letter followed by different lowercase letters in the superscript in a column are statistically different at $\mathrm{p}<0.05$ whereas values with a similar uppercase letter followed by similar lowercase letters are statistically similar at $p<0.05$. Values are means of triplicates for a sample and all the results are on a dry weight basis. The error bars represent the standard error. 


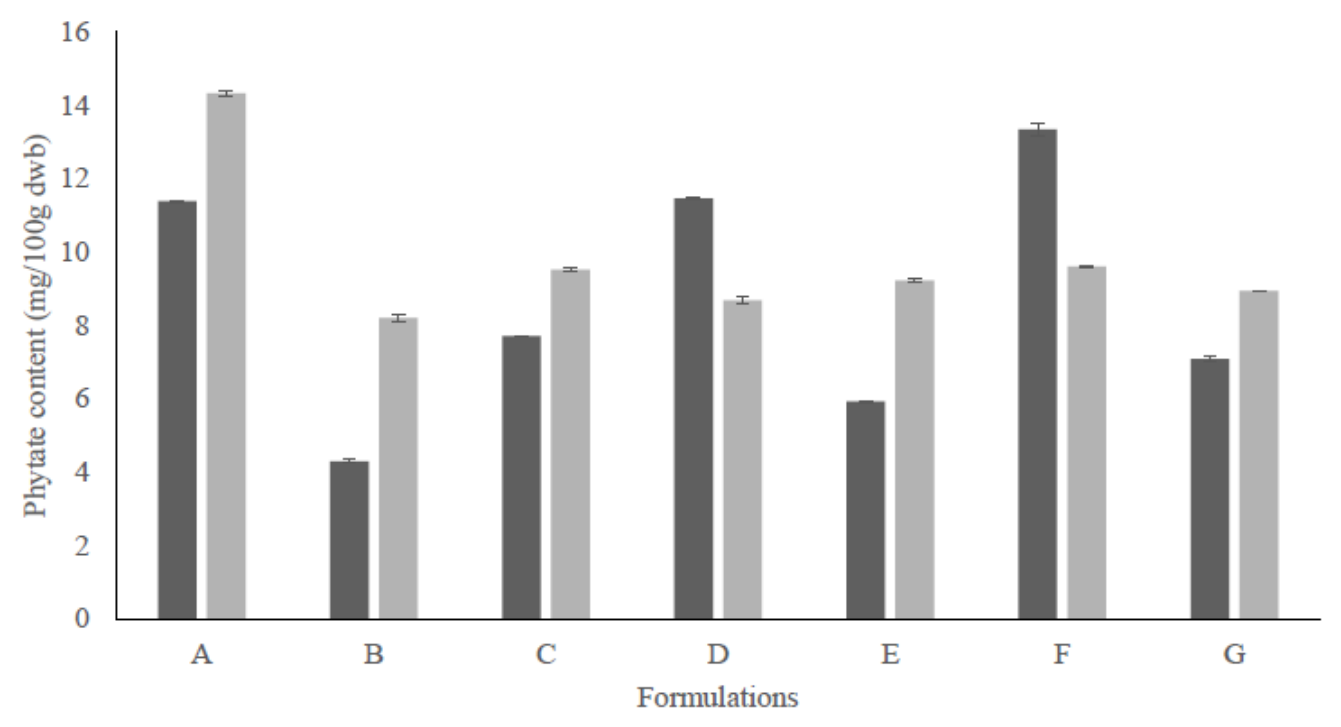

Extruded $\quad$ Not extruded

Figure 3. Effect of the interaction between extrusion and formulation on the phytate content of blended floursValues are means of triplicates for a sample. The error bars represent the standard error.

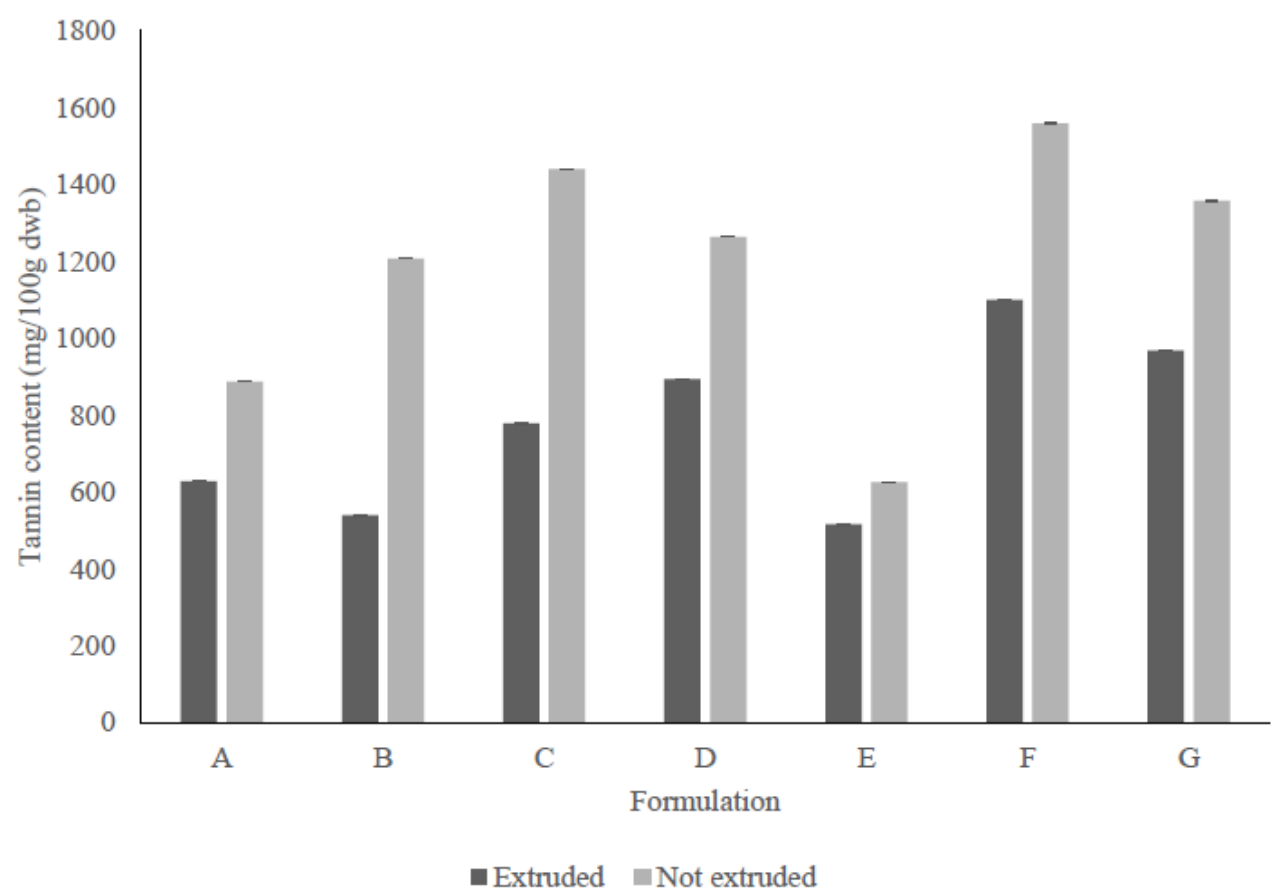

Figure 4. Effect of the interaction between extrusion and formulation on the tannin content of blended floursValues are means of triplicates for a sample. The error bars represent the standard error.

Table 8. Correlation between micronutrients and anti-nutrients in cereal flours

\begin{tabular}{lll}
\hline Micronutrient & \multicolumn{2}{l}{ Anti-nutrient } \\
\cline { 2 - 3 } & Phytates & Tannins \\
\hline Iron & -0.04 & -0.03 \\
Zinc & $0.45^{*}$ & -0.10 \\
\hline
\end{tabular}

*Value significant at $\mathrm{p}<0.05$ 


\section{Discussion}

\subsection{Nutrition Composition of Raw Material}

The findings in the present study showed amaranth and OFSP are the most nutritious fortificants of protein, beta-carotene and zinc in the formulations. The protein content for the amaranth grain found in this study was comparatively within the range of 13.37 to $23.28 \%$ reported by Kachiguma et al (Kachiguma et al., 2015) for various accessions grown in Malawi. However, Ayo, (2001) reported slightly a higher figure of $13.65 \%$ for the protein content. The range for the protein level reported by that particular study was $13.37 \%$ to $21.50 \%$. In proximate composition, baobab had the highest ash content pointing to higher mineral composition. OFSP was the only fortificant that had beta-carotene. In as much as drying of the OFSP roots deteriorates the level of beta-carotene through oxidation (Owade et al., 2018), the level of beta-carotene found in the current study was still higher than the levels reported by Aywa et al (Away et al., 2013) in some of the raw roots of some ascensions grown in Kenya. An earlier study by \{Formatting Citation\} found that maize flour had undetectable levels of beta-carotene, thus the $1987 \pm 0.05 \mu \mathrm{g}$ RAE$/ 100 \mathrm{~g}$ of vitamin A in OFSP flour makes it ideal as a fortificant. The two kinds of in this study had the highest contents of carbohydrates and energy values. Additionally, the drying of the fresh OFSP roots and grinding into flour has been shown to increase the carbohydrate contents of these ingredients seven-fold (Hacineza et al., 2007).

Considering that cereal flours are high in carbohydrate, this finding justifies the need to fortify the blended flours to increase their protein content.

\subsection{Anti-nutrient Content of Raw Materials}

Fortification of cereal flours that targets to increase their mineral content seeks to limit the anti-nutrient content of the specific flours. This is because of anti-nutrients such as phytic acid form complexes with micronutrients making them less bioavailable (Coulibaly et al., 2011). Evaluation of the cereal grains have shown that the content of anti-nutritional factors could be as high as $40-60 \%$ of the total caloric intake among the populations in SSA (Gupta et al., 2015); posing the risk of low bioavailability of micronutrients in the food taken. Sorghum and maize flours were found to have a higher content of tannin and phytate, respectively, than the fortificants. Increasing the tannin content of the cereal flour blend resulted in declining zinc content. This implies that improving the micronutrient content should not just be limited to the formulation of cereal flour blends with ingredients rich in zinc, additional treatment to address the anti-nutritional factors has to be applied.

\subsection{Proximate Composition of Blended Flours}

Incorporation of amaranth into the blended flours significantly improved the protein and ash content of the flours. The high protein content of the amaranth grain has been a selling point for its incorporation in food and feed whereby the augmentation of the feed and the food is the target (Ayo, 2001; Pisarikova et al., 2006). However, increasing the maize content had a reverse effect on the fibre content as it was decreasing. This is explained majorly by the low content of fibre in the maize grain compared to the other ingredients. The whole grain cereals are adjudged to be rich in fibre (Sarwar, 2013). Subsequently, incorporation of the fortificants into cereal flours resulted in the decreased energy density of the flours. The average energy values achieved in the extruded cereal flour blends was higher than the average energy values per gram of carbohydrate of $4 \mathrm{KCal}$. Most flour manufacturers usually add fats to increase the energy density of the flours (Okoth et al., 2017); however, in the present study, there was no addition of fat to the flour blends. Addition of fat in flour blends has a deleterious effect on the keeping quality of the flour as it decreases the shelf-life of the flour.

Extruded flour had a higher content of fat whereas reducing the ash, protein, carbohydrates and fibre contents. In their evaluation of flour fortification for the preparation of breakfast cereal, Santos et al (Santos et al., 2019) reported a threefold increase in the fat; increase that is higher than what was reported in the current study. This is attributed to the utilization of legumes which are known to be richer in oils in their study. The greatest decline in the protein content due to extrusion was seen in treatments with the highest amaranth content whereas the carbohydrates and energy values increased in samples with higher proportions of sorghum. The impact of extrusion on the proximate composition of extruded cereal flour has varied depending on the ingredients incorporated into the cereal flour. Whereas Yusuf et al (Yusuf et al., 2018) reported a decline in fibre as reported in this study, he reported contrary findings of an increase in the carbohydrate content of an extruded groundnut-sorghum flour blend. On the other hand, Tadesse et al., (2019) reported a decline in the carbohydrate content of an extruded soy-sorghum flour blend.

\subsection{Micronutrient and Anti-nutrient Content of Blended Flours}

In both extruded and non-extruded blended flours, the minimum beta-carotene level for fortified flours, 500 
$\mathrm{mg} / 100 \mathrm{~g}$ (Owade et al., 2018), was achieved. Incorporation of amaranth into cereal flour was reported to improve the iron and zinc whereas not achieving significant levels of vitamin A and its equivalents (Akande et al., 2017). Beta carotene was significantly reduced as a result of the extrusion process. Similar trends were reported by Akande et al., (2017) in their study that evaluated the effect of extrusion conditions on the nutrient composition of cereal flours. With increasing temperature of extrusion, it was reported that the vitamin A levels of the extruded flour declined. Cereal flour blends with OFSP rather than amaranth grain powder had higher degradation of the beta-carotene due to extrusion. Exposure of the OFSP to thermal treatment has been shown to result in degradation of the beta-carotene content through oxidation (Owade et al., 2018). Additionally, reduction in the moisture contents of the cereal flour blends resulted in a decline in the beta-carotene contents. This can be explained by the first order-kinetics of reduction of beta-carotene in dehydrated foods (Neto et al., 1981), whereby in low moisture beta-carotene deteriorates due to discolouration (Chou \& Breene, 1972; Pénicaud et al., 2011).

One of the greatest limitations of cereal-based flours in SSA is the bioavailability and content of the micronutrients (Tadesse et al., 2015). Utilization of locally available ingredients to develop nutrient dense formulations of the of cereal-based composite flour has been recommended as one of the affordable strategies to fight malnutrition especially among the under five years old children to whom porridge constitutes a great part of the diet (Akande et al., 2017). The levels of iron, zinc and beta-carotene achieved in the formulations were 4.29 \pm 0.02 to $28.19 \pm 2.67,1.46 \pm 0.09$ to $2.06 \pm 0.00$ and $280.3 \pm 1.3$ to $1320.8 \pm 13.1 \mathrm{mg} / 100 \mathrm{~g} \mathrm{dwb}$, which were higher than some of the levels reported for most rich sources including the indigenous vegetables such as cowpea leaves vastly consumed in SSA (NutriSurvey, 2007b, 2007a; Owade et al., 2019). The formulations in the present study thus serve as major food vehicles for the respective micronutrients especially to the most vulnerable population in SSA which are the children under the age of five years.

Extrusion lowered the anti-nutrient contents of the cereal-based composite flours by 10.6-35.0\%. The findings in this current study lend support to previous works by Gürbilek (Gürbilek, 2016) who reported a $16.55-50.85 \%$ decline in the anti-nutritional factors in sorghum flour blended cereal foods. Extrusion results in the destruction of inhibitory anti-nutritional factors such as phytic acids which lower the bioavailability of micronutrients in the cereals blended foods (Omosebi et al., 2018). On the other hand, increasing the sorghum ration in the cereal flours resulted in higher anti-nutrient content. The phytate content of the cereal flour blends with sorghum significantly reduced on extrusion. Phytate contents reported in cereals has been estimated at 0.18 to $6.39 \%$ with higher intake among those consuming whole wheat cereal; for phytic acid has a higher concentration in the bran (Gupta et al., 2015). These levels are higher than those in the formulation of the cereal flour blends which ranged between 0.006 and $0.012 \%$. Extrusion of the flour lowered the level of the phytate content by a further percentage. This is because extrusion hydrolyses phytic acid to phosphate molecules, thus destroying it (Wani \& Kumar, 2016). In the formulation of the cereal flour blends, precooking is thus recommended as a measure of improving the bioavailability of the zinc and iron (Gupta et al., 2015).

The extrusion also achieved a decline of $35.0 \%$ in the tannin content of the composite flours and an average tannin content of $0.78 \%$ was achieved. In animal studies, it has been established that serially increasing the tannin content in feeds from $0.00 \%$ to $0.02 \%$ showed a linear reduction in the haemoglobin and hepatic iron concentration (Delimont et al., 2017). Fortification seeks to minimize the anti-nutritional factors while increasing the micronutrient contents of the composite flours. With the increasing zinc contents, the phytic acid contents of the cereal flour blends also increased.

\section{Conclusion}

Incorporation of OFSP, baobab and amaranth in the maize-sorghum cereal flour blend increases the zinc, iron, protein and beta-carotene contents while reducing the tannin content of the composite flours. However, the phytic acid content of these flours increases with increasing proportions of the fortificants and reduction of the cereal flours. Fortification aims to improve the overall bioavailability of the nutrients in the formulation. To this end, extrusion of the flour blends reduces the level of anti-nutritional factors. In as much as the beta-carotene is degraded on extrusion, the minimum content of $500 \mu \mathrm{g} / 100 \mathrm{~g}$ for fortified foods is still achieved. This study provides input to the nutritional programmes and the ever-evolving dietary practices on the most cost-effective ways to alleviate micronutrient and protein deficiencies in SSA. Considering the value-chains of the ingredients used as fortificants in this study, the output of this study can be promoted as one of the possible ways for commercialization of these value chains.

\section{Acknowledgements}

The authors are grateful for the financial support received from United States Agency for International 
Development (USAID) Bureau for Food Security under Agreement \# AID-OAA-L-12-00003 as part of Feed the Future Innovation Lab for Food Processing and Post-harvest Handling.

\section{Conflict of Interest}

The authors declare that they have no conflict of interest concerning this research.

\section{References}

Abdulkarim, S. M., Bamalli, Z, G. M., \& Karim, R. (2014). Baobab Tree ( Adansonia digitata L ) Parts : Nutrition, Applications in Food and Uses in Ethno-medicine - A Review. Annals of Nutrition Disorders and Therapy, 1(3), 1-9. https://doi.org/10.13140/RG.2.1.1966.7602

Abong', G. O., Muzhingi, T., Wandayi, O. M., Ng'ang’a, F., Ochieng', P. E., Mahuga, M. D., \& Ghimire, S. (2020). Phytochemicals in leaves and roots of selected Kenyan Orange Fleshed Sweetpotato (OFSP) varieties. International Journal of Food Science, 2020, 1-11. https://doi.org/10.1155/2020/3567972

Adeyeye, S. A. O. (2016). Assessment of quality and sensory properties of sorghum-wheat flour cookies. Cogent Food \& Agriculture, 2(1), 1245059. https://doi.org/10.1080/23311932.2016.1245059

Akande, O. A., Nakimbugwe, D., \& Mukisa, I. M. (2017). Optimization of extrusion conditions for the production of instant grain amaranth-based porridge flour. Food Science and Nutrition, 5(6), 1205-1214. https://doi.org/10.1002/fsn3.513

AOAC. (2012). Official methods of analysis, Association of official analytical chemist (19th Editi). Washington D.C., USA. Retrieved from https://www.worldcat.org/title/official-methods-of-analysis-of-aoac-international/oclc/817542290

Asaam, E. S., Adubofuor, J., Amoah, I., \& Apeku, O. J. D. (2018). Functional and pasting properties of yellow maize-soya bean-pumpkin composite flours and acceptability study on their breakfast cereals. Cogent Food \& Agriculture, 4(1), 1-15. https://doi.org/10.1080/23311932.2018.1501932

Aslam, M. F., Ellis, P. R., Berry, S. E., Latunde-Dada, G. O., \& Sharp, P. A. (2018). Enhancing mineral bioavailability from cereals: Current strategies and future perspectives. Nutrition Bulletin, 43(2), 184-188. https://doi.org/10.1111/nbu.12324

Ayo, J. A. (2001). The effect of amaranth grain flour on the quality of bread. International Journal of Food Properties, 4(2), 341-351. https://doi.org/10.1081/JFP-100105198

Aywa, A. K., Nawiri, M. P., \& Nyambaka, H. N. (2013). Nutrient variation in coloured varieties of Ipomea batatas grown in Vihiga county, Western Kenya. International Food Research Journal, 20(2), 819-825. Retrieved from http://www.ku.ac.ke/schools/spas/images/nawiri2.pdf

Biswas, A. K., Sahoo, J., \& Chatli, M. K. (2011). A simple UV-Vis spectrophotometric method for determination of $\beta$-carotene content in raw carrot, sweet potato and supplemented chicken meat nuggets. LWT - Food Science and Technology, 44(8), 1809-1813. https://doi.org/10.1016/j.lwt.2011.03.017

Brown, K. H., Hambidge, K. M., \& Ranum, P. (2010). Zinc fortification of cereal flours: Current recommendations and research needs. Food and Nutrition Bulletin, 31(1 SUPPL.), 62-74. https://doi.org/10.1177/15648265100311s106

Chadare, F. J., Idohou, R., Nago, E., Affonfere, M., Agossadou, J., Fassinou, T. K., \& Hounhouigan, D. J. (2019). Conventional and food-to-food fortification: An appraisal of past practices and lessons learned. Food Science and Nutrition, 7(9), 2781-2795. https://doi.org/10.1002/fsn3.1133

Chanadang, S., \& Chambers, E. (2019). Determination of the sensory characteristics of traditional and novel fortified blended foods used in supplementary feeding programs. Foods, 8(2019), 261. https://doi.org/10.3390/foods8070261

Chou, H. E., \& Breene, W. M. (1972). Oxidative decolouration of B-carotene in low-moisture model systems. Journal of Food Science, 37(1), 66-68. https://doi.org/10.1111/j.1365-2621.1972.tb03387.x

Coulibaly, A., Kouakou, B., \& Chen, J. (2011). Phytic acid in cereal grains: structure, healthy or harmful ways to reduce phytic acid in cereal grains and their effects on nutritional quality. American Journal of Plant Nutritional and Fertilization Technology, 1(1), 1-22. https://doi.org/10.3923/ajpnft.2011.1.22

Delimont, N. M., Haub, M. D., \& Lindshield, B. L. (2017). The impact of tannin consumption on iron bioavailability and status: A narrative review. Current Developments in Nutrition, 1(2), 1-12. https://doi.org/10.3945/cdn.116.000042 
Ekpa, O., Palacios-Rojas, N., Kruseman, G., Fogliano, V., \& Linnemann, A. R. (2019). Sub-Saharan African maize-based foods - Processing practices, challenges and opportunities. Food Reviews International, 35(7), 609-639. https://doi.org/10.1080/87559129.2019.1588290

Ferreira, E. C., Nogueira, A. R. A., Souza, G. B., \& Batista, L. A. R. (2004). Effect of drying method and length of storage on tannin and total phenol concentrations in Pigeon pea seeds. Food Chemistry, 86(1), 17-23. https://doi.org/10.1016/j.foodchem.2003.08.024

Fraval, S., Hammond, J., Bogard, J. R., Ng'endo, M., van Etten, J., Herrero, M., \& van Wijk, M. T. (2019). Food access deficiencies in sub-Saharan Africa: Prevalence and implications for agricultural interventions. Frontiers in Sustainable Food Systems, 3(1), 104. https://doi.org/10.3389/fsufs.2019.00104

Gupta, R. K., Gangoliya, S. S., \& Singh, N. K. (2015). Reduction of phytic acid and enhancement of bioavailable micronutrients in food grains. Journal of Food Science and Technology, 52(1), 676-684. https://doi.org/10.1007/s13197-013-0978-y

Hacineza, E., Vasanthakaalam, H., Ndirigwe, J., \& Mukwantali, C. (2007). A comparative study on the $\beta$ -carotene content and its retention in yellow and orange-fleshed sweet potato flours. ASARECA, 143(3), 1252. Retrieved from http://www.plantphysiol.org/content/143/3/1252.short

Harika, R., Faber, M., Samuel, F., Mulugeta, A., Kimiywe, J., \& Eilander, A. (2017). Are Low Intakes and Deficiencies in Iron, Vitamin A, Zinc, and Iodine of Public Health Concern in Ethiopian, Kenyan, Nigerian, and South African Children and Adolescents? Food and Nutrition Bulletin, 38(3), 405-427. https://doi.org/10.1177/0379572117715818

Kachiguma, N. A., Mwase, W., Maliro, M., \& Damaliphetsa, A. (2015). Chemical and mineral composition of amaranth (Amaranthus L.) species collected from Central Malawi. Journal of Food Research, 4(4), 92. https://doi.org/10.5539/jfr.v4n4p92

Kulamarva, A. G., Sosle, V. R., \& Raghavan, G. S. V. (2009). Nutritional and rheological properties of sorghum. International Journal of Food Properties, 12(1), 55-69. https://doi.org/10.1080/10942910802252148

Latta, M., \& Eskin, M. (1980). A Simple and Rapid Colorimetric Method for Phytate Determination. Journal of Agricultural and Food Chemistry, 28(6), 1313-1315. https://doi.org/10.1021/jf60232a049

Manary, M., \& Callaghan-Gillespie, M. (2020). Role of Optimized Plant Protein Combinations as a Low-Cost Alternative to Dairy Ingredients in Foods for Prevention and Treatment of Moderate Acute Malnutrition and Severe Acute Malnutrition. Nestle Nutrition Institute Workshop Series, 93(1), 111-120. https://doi.org/10.1159/000503347

Mitchell, S., Gomes, A., Zelig, R., \& Parker, A. (2019). Not all grains are created equal: Gluten-free products not included in mandatory folate fortification. Current Developments in Nutrition, 3(5), 1-3. https://doi.org/10.1093/cdn/nzz020

Mounjouenpou, P., Ngono Eyenga, S. N. N., Kamsu, E. J., Bongseh, K. P., Ehabe, E. E., \& Ndjouenkeu, R. (2018). Effect of fortification with baobab (Adansonia digitata L.)pulp flour on sensorial acceptability and nutrient composition of rice cookies. Scientific African, l(1), e00002. https://doi.org/10.1016/j.sciaf.2018.e00002

Muthai, K. U., Karori, M. S., Muchugi, A., Indieka, A. S., Dembele, C., Mng'omba, S., \& Jamnadass, R. (2017). Nutritional variation in baobab (Adansonia digitata L.) fruit pulp and seeds based on Africa geographical regions. Food Science and Nutrition, 5(6), 1116-1129. https://doi.org/10.1002/fsn3.502

Ndemwa, M., Wanyua, S., Kaneko, S., Karama, M., \& Anselimo, M. (2017). Nutritional status and association of demographic characteristics with malnutrition among children less than 24 months in Kwale County, Kenya. The Pan African Medical Journal, 28(2017), 265. https://doi.org/10.11604/pamj.2017.28.265.12703

Neto, R. O. T., Karel, M., Saguy, I., \& MizrahiI, S. (1981). Oxygen uptake and B-carotene decolouration in a dehydrated food model. Journal of Food Science, 46(3), 665-669. https://doi.org/10.1111/j.1365-2621.1981.tb15319.x

NutriSurvey. (2007a). Nutrisurvey: Linear programming module. Retrieved from http://www.nutrisurvey.de/

NutriSurvey. (2007b). Nutrition surveys and calculations: Guidelines, software and additional information. Retrieved from www.nutrisurvey.de/lp/lp.htm

Okoth, J. K., Ochola, S. A., Gikonyo, N. K., \& Makokha, A. (2017). Development of a nutrient-dense complementary food using amaranth-sorghum grains. Food Science and Nutrition, 5(1), 86-93. 
https://doi.org/10.1002/fsn3.367

Omosebi, M. O., Osundahunsi, O. F., \& Fagbemi, T. N. (2018). Effect of extrusion on protein quality, antinutritional factors, and digestibility of complementary diet from quality protein maize and soybean protein concentrate. Journal of Food Biochemistry, 42(4), e12508. https://doi.org/10.1111/jfbc.12508

Owade, J.O., Abong, G. O., \& Okoth, M. W. (2018). Production, utilization and nutritional benefits of orange-fleshed sweet potato (OFSP) puree bread: A review. Current Research in Nutrition and Food Science, 6(3), 644-655. https://doi.org/10.12944/CRNFSJ.6.3.06

Owade, Joshua O, Abong, G., Okoth, M., \& Mwang, A. W. (2019). A review of the contribution of cowpea leaves to food and nutrition security in East Africa. Food Science and Nutrition, 8(1), 36-47. https://doi.org/10.1002/fsn3.1337

Pénicaud, C., Achir, N., Dhuique-Mayer, C., Dornier, M., \& Bohuon, P. (2011). Degradation of $\beta$-carotene during fruit and vegetable processing or storage: Reaction mechanisms and kinetic aspects: A review. Fruits, 66(6), 417-440. https://doi.org/10.1051/fruits/2011058

Pisarikova, B., Zraly, Z., Kracmar, S., Trckova, M., \& Herzig, I. (2006). The use of amaranth (genus Amaranthus L.) in the diets for broiler chickens. Veterinarni Medicina, 51(7), 399-407. https://doi.org/10.17221/5560-VETMED

Puwastien, P., Siong, T. E., Kantasubrata, J., Craven, G., \& Feliciano, R. R., \& Judprasong, K. (2011). Manual of Food Analysis. Springer International Publishing. Retrieved from http://link.springer.com/10.1007/978-3-319-45776-5

R Core Team. (2019). $R$ : A language and environment for statistical computing. Vienna, Austria: R Foundation for Statistical Computing. Retrieved from https://www.r-project.org/

Santos, I. L., Schmiele, M., Aguiar, J. P. L., Steel, C. J., Silva, E. P., \& Souza, F. das C. do A. (2019). Evaluation of extruded corn breakfast cereal enriched with whole peach palm (Bactris gasipaes, Kunth) Flour. Food Science and Technology, 40(2),458-464. https://doi.org/10.1590/fst.04019

Sarwar, H. (2013). The importance of cereals (Poaceae: Gramineae) nutrition in human health: A review. Journal of Cereals and Oilseeds, 4(3), 32-35. https://doi.org/10.5897/jco12.023

Stefoska-Needham, A., Beck, E. J., Johnson, S. K., \& Tapsell, L. C. (2015). Sorghum: An Underutilized Cereal Whole Grain with the Potential to Assist in the Prevention of Chronic Disease. Food Reviews International, 31(4), 401-437. https://doi.org/10.1080/87559129.2015.1022832

Tadesse, S. A., Beri, G. B., \& Abera, S. (2019). Chemical and sensory quality of sorghum-based extruded product supplemented with defatted soy meal flour. Cogent Food \& Agriculture, 5(1), 1-19. https://doi.org/10.1080/23311932.2019.1653617

Tadesse, T. F., Nigusse, G., \& Kurabachew, H. (2015). Nutritional, microbial and sensory properties of flat-bread (kitta) prepared from blends of maize ( Zea mays 1.) and orange-fleshed sweet potato (Ipomoea batatas 1.) flours. International Journal of Food Science and Nutrition Engineering, 5(1), 33-39. https://doi.org/10.5923/j.food.20150501.05

Tanimola, A. R., Otegbayo, B., \& Akinoso, R. (2016). Chemical, functional, rheological and sensory properties of amaranth flour and amaranth flour-based paste. African Journal of Food Science, 10(11), 313-319. https://doi.org/10.5897/ajfs2016.1422

Ukom, A. N., Adiegwu, E. C., Ojimelukwe, P. C., \& Okwunodulu, I. N. (2019). Quality and sensory acceptability of yellow maize ogi porridge enriched with orange-fleshed sweet potato and African yam bean seed flours for infants. Scientific African, 6(1), e00194. https://doi.org/10.1016/j.sciaf.2019.e00194

Van Ittersum, M. K., Van Bussel, L. G. J., Wolf, J., Grassini, P., Van Wart, J., Guilpart, N., \& Cassman, K. G. (2016). Can sub-Saharan Africa feed itself?. Proceedings of the National Academy of Sciences of the United States of America, 113(52), 14964-14969. https://doi.org/10.1073/pnas.1610359113

Vila-Real, C., Pimenta-Martins, A., Maina, N., Gomes, A., \& Pinto, E. (2017). Nutritional value of African Indigenous whole-grain cereals millet and sorghum. International Journal of Nutrition and Food Science, 4(1), 001-005. https://doi.org/10.19080/NFSIJ.2017.03.555628

Wani, S. A., \& Kumar, P. (2016). Effect of Extrusion on the Nutritional, Antioxidant and Microstructural Characteristics of Nutritionally Enriched Snacks. Journal of Food Processing and Preservation, 40(2), 166-173. https://doi.org/10.1111/jfpp.12593 
WHO/FAO. (2003). Food energy - methods of analysis and conversion factors. Report of a technical workshop. Fao Food and Nutrition Paper.

Yusuf, M., Halilu, M., \& Filli, K. (2018). Influence of extrusion variables on proximate composition some nutrient and antinutrient contents of Dakuwa extrudates Produced from blends of sorghum (Sorghum bicolour L) Groundnut (Arachis hypogea L) and Tigernut (Cyperus esculentus). Current Journal of Applied Science and Technology, 26(4), 1-20. https://doi.org/10.9734/cjast/2018/40037

\section{Copyrights}

Copyright for this article is retained by the author(s), with first publication rights granted to the journal.

This is an open-access article distributed under the terms and conditions of the Creative Commons Attribution license (http://creativecommons.org/licenses/by/4.0/). 